\title{
CONTRASTES REGIONAIS NO DESENVOLVIMENTO ECONOMICO BRASILEIRO
}

\section{HEINRICH RATTNER}

\begin{abstract}
"É da incumbência dos economistas reconhecer e proclamar que o progresso económico não é, simplesmente, um problema de mais capital, mais acres ou mais carvão, senão, também, um problema de maior eficiência na administração e nos esforços para obter melhor educação, melhor saúde, melhor motivação e melhor organização politica e social."

- JACOB VINER
\end{abstract}

A economia brasileira, considerada globalmente, apresenta ao observador o quadro típico de um país em plena fase de desenvolvimento. O crescimento de um parque industrial moderno, a diversificação dos produtos exportados e importados, a racionalização e burocratização do aparelho político e administrativo são apenas alguns dos aspectos mais característicos que aproximam a sociedade brasileira dos padrões dos países desenvolvidos do Ocidente.

Todavia, um exame mais minucioso revela-nos uma disparidade interna muito acentuada quanto ao ritmo e à intensidade do processo de desenvolvimento brasileiro. E assim que vemos, ao lado de uma economia dinâmica e relativamente próspera, concentrada em redor dos grandes núcleos agrindustriais da região Sul-Sudeste do País, persistir nas demais regiões um tipo de produção primitiva,

HEINRICH RATNER - Professor (contratado) de Sociologia, do Depto. de Ciências Sociais, da Escola de Administração de Emprêsas de São Paulo e Instrutor da Cadaira de Economia Política, da Faculdade de Filosofia, Ciências e Letras, da Universidade de São Paulo. 
bastante apenas para assegurar aos seus habitantes, alheios ao progresso econômico, social e cultural, um nível de vida rudimentar.

Entretanto, mais importante do que a própria constatação dêsse fato é a análise das tendências do processo e suas possíveis consequiências sôbre o futuro social e político da Nação. Eis porque elegemos, como principais objetivos do presente trabalho. os seguintes pontos:

- Testar algumas das hipóteses de Colin Clark e Simon Kuznets, a respeito da modificação da importância relativa dos setores primário, secundário e terciário, à medida que se processa o desenvolvimento econômico. ${ }^{1}$ Empregamos para tanto dados parciais (relativos a São Paulo e ao Nordeste) e globais (do Brasil em geral).

- Aferir, por meio de dados estatísticos, o já famoso processo de concentração industrial que vem ocorrendo em São Paulo.

- Analisar as tendências e os resultados do desenvolvimento econômico brasileiro, em seus aspectos regionais, comparando os dados disponíveis, em escala nacional, com os do maior núcleo industrial do País, o Estado de São Paulo, e com os da região mais atrasada e pobre, o Nordeste. Selecionamos, para tal fim, diferentes dados relativos: à evolução demográfica do País; às tendências do processo de concentração industrial; e ao crescimento do produto real e da renda per capita.

- Identificar alguns procedimentos de caráter econômico-social que, se adotados com objetivos políticos, poderiam favorecer o desenvolvimento mais harmônico da economia brasileira.

Não pretendemos advogar soluções parciais e isoladas para o problema do subdesenvolvimento regional. Quisemos

1) Simon KuzNets, Six Lectures on Economic Grcwth, John Hopkins University e Colin Clark, The Conditions of Economic Progress, MacMillan and Co., Londres, 1959, .caps. V, VI e VII, págs. 193 a 349. 
apenas ressaltar que qualquer programa ou plano de desenvolvimento, de âmbito nacional, que não preconize meios e caminhos para reduzir as disparidades regionais e, assim, aproximar os extremos, estará fatalmente destinado ao malôgro.

Segundo Kuznets, o desenvolvimento econômico dos países subdesenvolvidos é caracterizado por dois aspectos específicos :

- em todos os casos o desenvolvimento econômico acarreta uma elevação constante e substancial do produto per capita;

- em quase todos os casos, êle implica um crescimento constante e substancial da população.?

Todavia, um aumento quantitativo dêsses índices não é, necessàriamente, sinônimo do desenvolvimento, a não ser que seja acompanhado por mudanças estruturais e institucionais, como a urbanização, a educação democrática e universal e a ascendente mobilidade social que daí advém. O esteio do desenvolvimento é constituído por uma alta taxa de acumulação de capital, conseguida, muitas vêzes, por uma poupança forçada, por reinvestimentos planejados e dirigidos e por um aumento constante da produtividade da fôrça de trabalho. O equipamento físico, ou seja, bens de capital, e o progresso técnico são condições necessárias, mas não suficientes para o aumento da produtividade; é indispensável que a população ativa tenha a capacidade de utilizá-los efetiva e racionalmente. Destarte, a estratificação da população, sua distribuição em áreas urbanas e rurais, e seu conseqüente nível educacional e cultural, são fatôres de suma importância para a análise de tôdas as fases do desenvolvimento econômico.

Quanto mais atrasado econômicamente o país, tanto maior será a parte da agricultura em sua economia, quer no tocante à participação no total da renda nacional, quer no que se refere aos efetivos da população ativa que se dedi-

2) Simon KuzNets, op. cit., pág. 14. 
cam a atividades primárias. Assim, por via de regra, a maior parte da população ativa de um país, no início do processo de desenvolvimento, está concentrada em atividades do setor primário, com baixa produtividade. À medida que o crescimento econômico resulta, principalmente, do fato de a produção industrial ser introduzida e aplicada, o conhecimento técnico e científico moderno, no qual essa produção está estribada, exige e provoca mudanças na estrutura demográfica e social dêsse país.

GRÁFICO i: MUDANÇAS NA ESTRUTURA DEMOGRÁFICA BRASILEIRA $(1940-1960)$

1 - A: COMPOSIÇão dA POPULAÇÃo

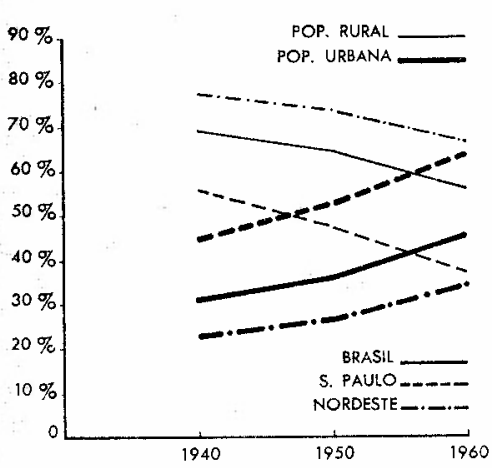

1 - C TAXAS dF CRESGIMENTO DA POPULAÇÄO BRASILLIRA

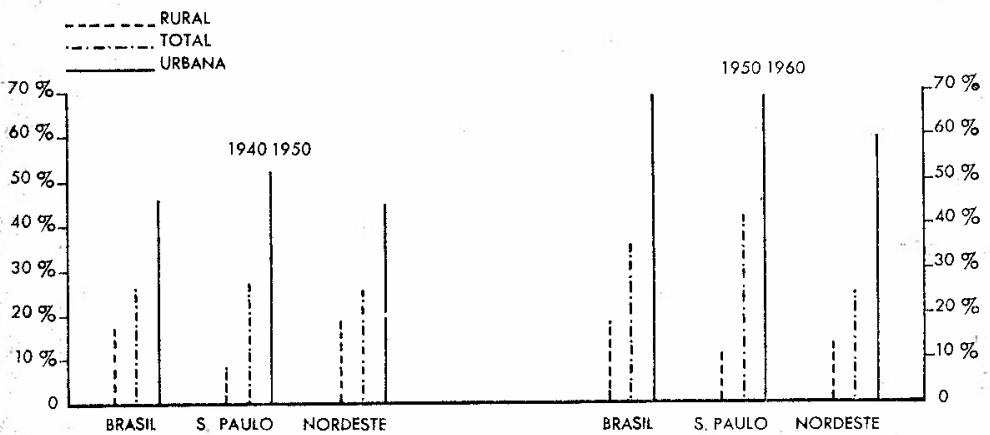


No Brasil, entretanto, a percentagem da população ativa no setor agropecuário excede em muito sua participação percentual no produto real total do País, refletindo, dessa maneira, a menor produtividade e a menor renda per capita das pópulações rurais brasileiras, em escala nacional, e a relativa pobreza da população brasileira, em escala internacional.

Todavia, o exame das estatísticas gerais da economia nacional não basta para perceber os problemas críticos do desenvolvimento econômico. As discrepâncias regionais em nível de renda e taxa de crescimento são, às vêzes, tão grandes que qualquer índice médio nacional se torna absolutamente inexpressivo das verdadeiras tendências do processo. No caso brasileiro, segundo o Conselho Nacional de Economia, "o desnível da distribuição de rendas, observado nas diversas regiões do País, além de atrapalhar o desenvolvimento do Brasil, está comprometendo, até mesmo, a unidade nacional". 3

\section{ASPECTOS DEMOGRÁFICOS}

O desenvolvimento econômico de uma região ou de um país subdesenvolvido é acompanhado, de um lado, pela concentração, cada vez maior, da população em áreas urbanas e, de outro lado, pelo êxodo rural da mão-de-obra ativa. No caso brasileiro o movimento da população nos diferentes Estados federados tem seguido essa tendência, embora em ritmo e intensidade diferentes.

Os dados apresentados no Gráfico 1, cujos números estão reproduzidos no Anexo 1, permitem analisar os aspectos quantitativos e qualitativos, ou seja, os estratos fundamentais da sociedade brasileira e a dinâmica de seu desenvolvimento. O aumento constante da população urbana no conjunto da população do País, verificado nos dois últimos decênios, significa elevada mobilidade espacial e, por não ter provocado desemprêgo em massa nas áreas urbanas,

3) "10." Exposição Geral da Situação Econômica do Brasil”, Rio de Janeiro, 1963, citado no $O$ Estado de São Paulo de 11/9/1963. 
ascensão social de amplas parcelas da população brasileira. Segmentos sempre crescentes da população rural, antes ocupados em atividades primárias, com baixíssimas rendas per capita, passam, em consequiência da inđustrialização, para atividades secundárias e terciárias com maior produtividade e, também, maior nível de renda.

Entre 1950 e 1960 a população total do Brasil aumentou de $36,6 \%$. Na década anterior o aumento havia sido de apenas $26,0 \%$. Nos mesmos períodos, porém, as respectivas taxas de crescimento para a população urbana foram de 70,0 e $45,7 \%$, enquanto a população rural aumentou apenas 17,7 e $16,9 \%$. A discrepância é maior quando comparadas essas taxas com as do Estado de São Paulo e as do Nordeste. Em São Paulo, nos períodos de 1940 a 1950 e de 1950 a 1960, verificamos os seguintes índices de crescimento populacional: 27,2 e $42,0 \%$ para a população total; 51,6 e $69,6 \%$ para a população urbana, e sòmente 7,9 e $11,1 \%$ para a população rural.

Em sete Estados da região nordestina (Alagoas, Pernambuco, Paraíba, Rio Grande do Norte, Ceará, Piauí e Maranhão) as taxas foram, respectivamente: 23,3 e $25,5 \%$, para a população total; 44,9 e $61,1 \%$, para a população urbana; 19,5 e 12,8\%, para a população rural.

Enquanto os índices de crescimento da população no primeiro decênio foram mais ou menos idênticos para as três unidades (respectivamente, 26,0, 27,2 e 25,3\%), na década seguinte, de 1950 a 1960 , caracterizada pelo surto industrial em escala ampla e em intensidade e ritmo acelerados, os mesmos índices mostraram um incremento bastante diferente: $36,2 \%$ - Brasil; 42,0\% - São Paulo, e apenas 25,5\% - Nordeste. Entretanto, o aumento aparente na taxa de crescimento da população urbana no Nordeste, entre 1950 e 1960 , não se manifestou favorável ao desenvolvimento econômico da região, o que é evidenciado, entre outros fatôres, pela proporção muito baixa da população ativa comparada ao conjunto populacional nordestino. 


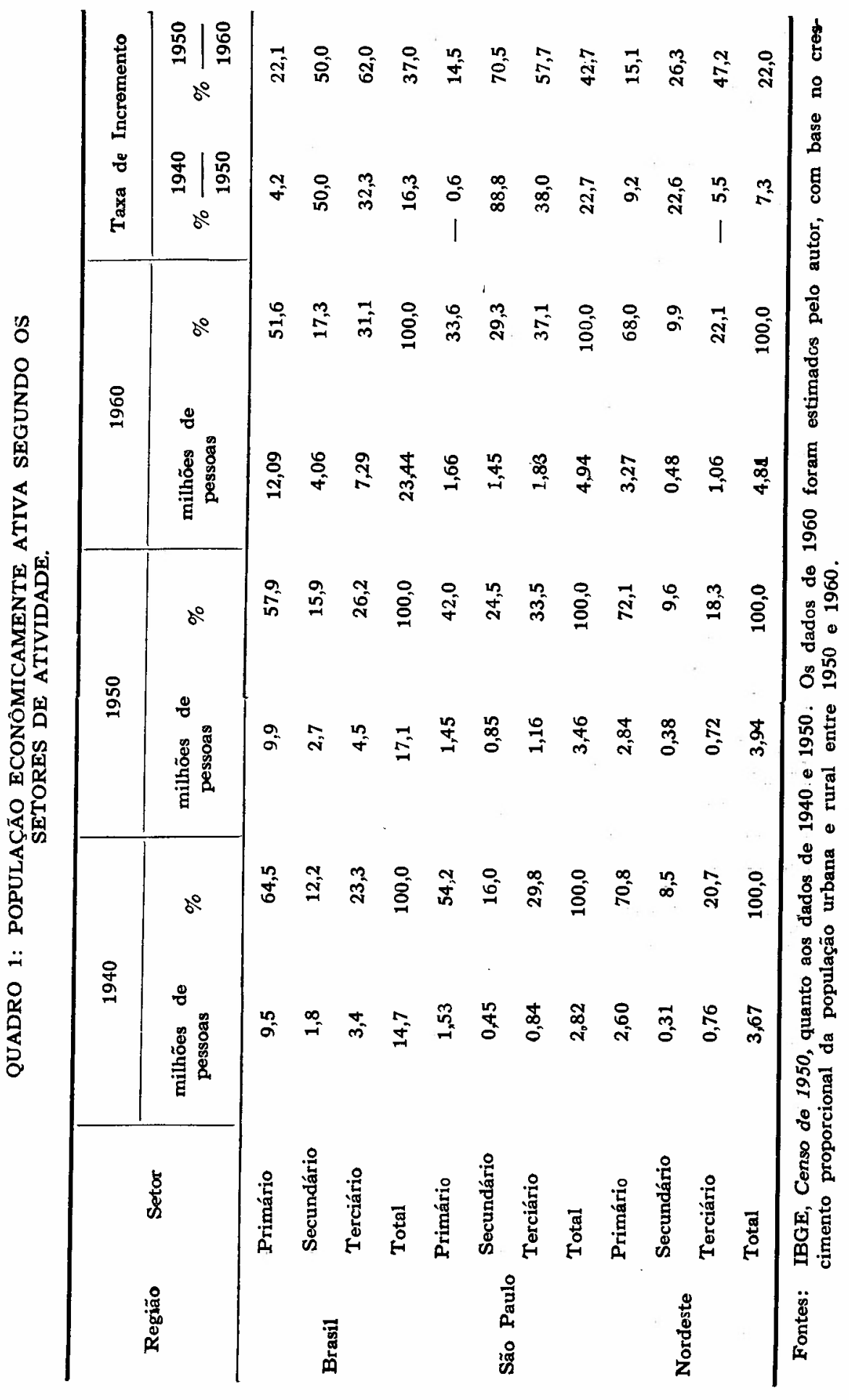


Em $196033 \%$ da população total do Brasil exerceram atividades produtivas nos três setores: primário, secundário e terciário, contra 38,2\% no Estado de São Paulo e apenas $30,6 \%$ no Nordeste. Êsse dado é sobremodo significativo, porquanto é sabido que, quanto mais desenvolvido um país, tanto mais alta é a proporção de sua população ativa no total populacional .

Nos Estados Unidos, por exemplo, essa cifra alcança $40 \%$, e nos países da Europa Ocidental vai a $46 \%$. O desenvolvimento econômico implica, inevitàvelmente, um processo de "ativação" pela transferência de pessoas do grupo inativo para o ativo, na medida em que surgem novas oportunidades de emprêgo. Porém, nem sempre o aumento da população urbana é conseqüência de um processo de industrialização e expansão econômica. No caso du Nordeste, por exemplo, o fenômeno da concentração mais rápida da população urbana decorre das sêcas periódicas, da miséria e da fome; as massas rurais, mudando para as cidades, não se transformam em elementos produtivos: tornam-se clientela dos serviços assistenciais do Estado. Para melhor ilustrar êsse fato é necessário analisar a distribuição intersetorial da população ativa, ou seja, os contingentes ocupados na agropecuária, na indústria e nos diversos serviços, o que é feito no Quadro 1 .

Como já lembramos, é fato conhecilo que, quanto mais subdesenvolvido um país, tanto maior é a parte da agricultura em sua economia, enquanto nos países de renda per capita mais elevada, essa participação é progressivamente menor. A importância das atividades primárias no conjunto da economia de um país constitui, portanto, índice altamente significativo de progresso, sendo possível medi-lo por sua contribuição à renda nacional ou pelos efetivos demográficos nelas ocupados.

A tendência pela diminuição da populaçáa ocupada en atividades primárias é evidente pelos dados alinhados no Quadro 1 e no Anexo 2. O ritmo dêsse processo, porém, é diferente, segundo as diferentes unidades da Federação. Assim, em 1940, ainda 70,0\% da população ativa brasi- 
leira estava ocupada na agropecuária, contra 58,0\% em 1950 e, finalmente, $51,6 \%$ em $1960 .{ }^{4}$ No mesmo período, isto é, durante essas duas décadas, a população rural ativa do Nordeste representava, respectivamente, 70,8, 72,1 e $68,0 \%$ do total dos ativos. No Estado de São. Paulo os respectivos resultados foram $54,2,42,0$ e $33,6 \%$ para $1940 / 50 / 60$.

Enquanto no conjunto da população ativa brasileira houve uma redução de $18,4 \%$ na população rural ativa, em São Paulo essa redução alcançou $20,2 \%$ e, no Nordeste, apenas $2,8 \%$, durante os últimos vinte anos, como se pode notar, mais pormenorizadamente, no Anexo 2 .

\section{QUADRO 2: PARTICIPAÇÃO DA POPULAÇÃo ATIVA NA RENDA NACIONAL}

\begin{tabular}{|c|c|c|c|c|c|c|c|}
\hline \multirow{3}{*}{ Região } & \multirow{3}{*}{ Ano } & \multicolumn{3}{|c|}{ População Ativa (\%) } & \multicolumn{3}{|c|}{ Contrib. à Renda Nacional ( $\%$ ) } \\
\hline & & & Setores & & & Setores & \\
\hline & & primário & secund. & terciário & secund. & primário & terciário \\
\hline \multirow{2}{*}{ Brasil } & 1950 & 57,5 & 15,8 & 26.7 & 28,6 & 23,8 & 47,5 \\
\hline & 1960 & 51,6 & 17,3 & 31,1 & 28,5 & 26,1 & 45,4 \\
\hline \multirow{2}{*}{ S. Paulo } & 1950 & 42,0 & 24,5 & 33,5 & 29,8 & 28,3 & 41,9 \\
\hline & 1960 & 33,6 & 29,3 & 37,1 & 23,4 & 33,2 & 43,4 \\
\hline \multirow{2}{*}{ Nordeste } & 1950 & 72,1 & 9,6 & 18,3 & 42,1 & 13,4 & 44,5 \\
\hline & 1960 & 68,0 & 9,9 & 22,1 & 47,3 & 11,1 & 41,6 \\
\hline
\end{tabular}

Fontes dos dados brutos: população ativa em 1950: IBGE, Censo de 1950; Revista Brasileira de Economia, Fundação Getúlio Vargas, Rio de Janeiro, ns. $1 / 1959$ e $1 / 1962$.

O Quadro 2 dá-nos uma comparação entre a participação percentual da população ativa, nos diversos setores das ati-

4) Este último dado é estimativo; quando êste trabalho foi escrito os dados do censo de 1960 não estavam ainda disponíveis. 
vidades econômicas, e sua participação relativa na renda nacional.

Uma das primeiras inferências tiradas dos dados acima é a baixa produtividade das atividades primárias, no conjunto da economia brasileira. Assim, por exemplo, 51,6\% da população ativa, concentradas na agropecuária, contribuíram, em 1960, com apenas $28,5 \%$ na formação da renda nacional. Essa desproporção torna-se mais sensível quando considerados os respectivos índices para a região nordestina: $68,0 \%$ da população ativa no setor primário fornecem $47,3 \%$ da renda total da região, como se pode ver, também, no Anexo 2, no qual se incluem dados das diversas regiōes geoeconômicas do Brasil. Em outras palavras: no Nordeste, ainda hoje, 68 homens trabalham na agropecuária a fim de produzir os alimentos para 100 trabalhadores e suas famílias, enquanto no Estado de São Paulo, essa proporção é menor do que a metade da do Nordeste, ou seja, 33,6\% e, nos países econômicamente mais adiantados, como a Alemanha, EUA, Canadá e Grã-Bretanha, ela varia entre 5 e $10,0 \%$.

A baixa produtividade do setor primário influi, necessàriamente, sôbre os níveis te renda, global e per capita, do total da fôrça de trabalho da nação. Segundo Kuznets, uma das condições prévias da industrialização é um aumento substancial da produtividade do trabalho agrícola, para que, com seus produtos, possam ser alimentados em níveis per capita mais elevados do que antes, os contigentes cada vez maiores da fôrça de trabalho global do país. ${ }^{5}$

A falta de modernização no equipamento, o desconhecimento de métodos e técnicas de lavoura conformes às conquistas da ciência e, finalmente, a deficiência, em educação e saúde, dos homens rurais, mantêm em nível muito baixo a produtividade da agricultura e, assim, criam um desequilíbrio perigoso entre esta e alguns setores de produção mais avançados (inđústria de transformação, petro-

5) Simon KuzNETs, op. cit., págs. 59 e 60 . 
química etc.), o que provoca problemas e tensões inter-regionais, que se refletem sôbre a estabilidade das estruturas sociais e políticas do País. Ademais, o desequilíbrio se manifesta, principalmente, nas tendências inflacionárias dos preços de alimentos e outros produtos agrícolas, cuja oferta não consegue acompanhar o ritmo crescente da demanda exercida pelas populações concentradas em áreas urbanas e ocupadas na indústria e nos serviços.

O jôgo das fôrças do mercado tende a aumentar, em vez de diminuir, as desigualdades existentes entre as diversas regiões do País caracterizadas acima. A menos que os podêres públicos interfiram no sentido de coordenar e planejar o processo de expansão econômica, as atividades indutriais, comerciais, bancárias, securitárias, de transporte, de comunicações, enfim, quase tôdas as atividades de maior rendimento per capita, bem como as educacionais, artísticas, científicas e culturais, tôdas tendem a concentrar-se em algumas localidades e regióes, deixando o resto do país mais ou menos estagnado. Concomitantemente, as regiões mais ricas e, por isso mesmo, mais influentes nos destinos políticos da Nação conseguem impor leis e regulamentos que as favorecem economica e financeiramente, muito embora em detrimento das regióes mais pobres. Exemplo típico dêsse fenômeno foi a canalização de divisas fortes entradas no país através de exportações de produtos da região nordestina (algodão, açúcar, cacau etc.) para os centros industriais do Sul. A política de subsídios que vigorou principalmente de 1947 a 1953, através de favores cambiais para importação de equipamentos industriais, beneficiou, necessàriamente, as regiões em vias de expansão industrial, transferindo-lhes as rendas em cambiais, enquanto baixava ainda mais a renda das regiões tìpicamente exportadoras de produtos agrários. ${ }^{6}$

Outro fator que aumenta o desequilíbrio entre as regiões mais industrializadas e aquelas onde predominam ativida-

6) A influência dessa política pode ser auferida do quadro publicado no Plano Trienal de Desenvolvimento Econômico e Social, pág. 83. 
des primárias é o processo constante de migração seletiva. Os elementos mais produtivos, isto é, de melhor idade e com maior fôrça de trabalho, abandonam as regiões que não lhes oferecem meios de vida, buscando empregos mais rendosos e seguros nos centros industriais e comerciais da região Sul.

As comunidades rurais ficam, portanto, duplamente espoliadas e prejudicadas: a relação desfavorável existente entre a população ativa e os recursos técnicos e naturais à sua disposição torna-se ainda mais acentuada pela alta taxa de natalidade, combinada com uma diminuição da mortalidade, esta afetada mais ràpidamente pelas técnicas moldernas de higiene pública. Por outro lado, devido à falta de recursos, as oportunidades e facilidades educacionais não aumentam na proporção necessária, criando o baixo nível educacional da mão-de-obra obstáculos e problemas para a implantação de um parque industrial moderno.

Convém, a título de ilustração, examinar os Quadros 3 e 4, onde são agrupados dados referentes à proporção de matrículas do ensino primário, no total da população e, também, a relação entre matrículas e aprovações, no Nordeste, em São Paulo e no Brasil. No Nordeste os baixos índices de matrículas e conclusões de curso, bem como o núme-

QUADRO 3: MATRICULAS NO ENSINO PRIMÁRIO FUNDAMENTAL

\begin{tabular}{|c|c|c|c|c|c|c|}
\hline \multirow[b]{3}{*}{ Região } & \multicolumn{3}{|c|}{1955} & \multicolumn{3}{|c|}{1960} \\
\hline & \multirow{2}{*}{$\begin{array}{l}\text { População } \\
\qquad \begin{array}{c}(1.000 \\
\text { habs. })\end{array}\end{array}$} & \multicolumn{2}{|c|}{ Matrículas } & \multirow{2}{*}{$\begin{array}{c}\text { População } \\
(1.000 \\
\text { habs. })\end{array}$} & \multicolumn{2}{|c|}{ Matrículas } \\
\hline & & $\begin{array}{l}\text { (em 1.000 } \\
\text { unidades) }\end{array}$ & $\begin{array}{l}\text { (por } \\
1.000 \\
\text { habs.) }\end{array}$ & & $\begin{array}{l}\text { (em } 1.000 \\
\text { unidades) }\end{array}$ & $\begin{array}{r}\text { (por } \\
1.000 \\
\text { habs.) }\end{array}$ \\
\hline Brasil & 60.183 & $4.777,7$ & 79 & 70.967 & $6.404,0$ & 90 \\
\hline S. Paulo & 10.789 & $1.011,3$ & 94 & 12.975 & $1.353,8$ & 104 \\
\hline Nordeste & 13.855 & 828,1 & 60 & 15.678 & $1.047,8$ & 67 \\
\hline
\end{tabular}

Fonte dos dados brutos: IBGE, Anuário Estatístico do Brasil, 1958 e 1960. 
to relativa e absolutamente baixo de matrículas por 1.000 1:á:itantes, são gravados pelas seguintes circunstâncias:

- Devido à alta taxa de natalidade e à migração dos homens em idade de trabalhar, o número de crianças na população nordestina é proporcionalmente maior do que no Estado de São Paulo.

- A "expectativa média de vida" ou, em outras palavras, o número de "velhos" é proporcionalmente menor no Nordeste do que no Estado de São Paulo, em consequiência da pobreza, da falta de educação e de padrões sanitários eficientes naquela região.

QUADRO 4: MATRÍCULAS EFETIVAS E CONCLUSÕES DE CURSO NO ENSINO PRIMARIO FUNDAMENTAL (de 1955 e 1960)

\begin{tabular}{|c|c|c|c|c|c|}
\hline Regiōes & $\begin{array}{l}\text { Matrículas } \\
\text { Efetivas }\end{array}$ & $\begin{array}{c}\% \text { sôbre } \\
\text { total }\end{array}$ & $\begin{array}{llll}1 & 9 & 5 & 5 \\
\text { Conclusões }\end{array}$ & $\begin{array}{c}\% \text { sôbre } \\
\text { total }\end{array}$ & $\begin{array}{c}\% \text { concl. } \\
\text { matric. }\end{array}$ \\
\hline T*nsil & $4.777,7$ & 100,0 & 395,1 & 100,0 & 8,2 \\
\hline$\because$ Paulo & $1.011,3$ & 21,2 & 151,0 & 38,2 & $.14,9$ \\
\hline$y^{\prime}-$ doste & 828,1 & 17,3 & 26,0 & 6,8 & 3,1 \\
\hline R:-giões & $\begin{array}{l}\text { Matrículas } \\
\text { Efetivas }\end{array}$ & $\begin{array}{l}\% \text { sôbre } \\
\text { total }\end{array}$ & $\begin{array}{c}1960 \\
\text { Conclusões }\end{array}$ & $\begin{array}{c}\% \text { sôbre } \\
\text { total }\end{array}$ & $\begin{array}{l}\% \text { conc1. } \\
\text { matric. }\end{array}$ \\
\hline$=: a s i 1$ & $6.404,0$ & 100,0 & 549,6 & 100,0 & 8,6 \\
\hline So Paulo & $1.353,8$ & 21,1 & 180,9 & 32,9 & 13,4 \\
\hline$\because \cdot-$ d $\approx$ ste & $1.047,8$ & 16,3 & 38,1 & 6,9 & 3,6 \\
\hline
\end{tabular}

Znce des dados brutos: IBGE, Anuário Estatístico do Brasil, 1958 e 1962.

Vaíc äizer que, apesar de uma estrutura etária mais jovem, que exige índices de matrícula e de conclusão de curso mais elevados do que no resto do País, êsses índices no Nerçeste continuam muito abaixo da média nacional. 
CONCENTRAÇÃO DA PRODUÇÃO INDUSTRIAL

O desenvolvimento econômico contemporâneo é resultado, principalmente, da introdução do sistema industrial, isto é, de um processo de produção baseado na aplicação e no uso crescente do conhecimento científico moderno. As mudanças na subestrutura e a passagem de atividades predominantemente agropecuárias para a indústria e serviços, associadas com a elevação da renda per capita durante êsse processo, motivam a identificação do desenvolvimento com a urbanização e a industrialização. Requisito do desenvolvimento, essencial para assegurar seu sucesso, é a diminuição da desigualdade intersetorial, em produto $e$ renda per capita, existente no início, sob pena de ver-se embaraçado ou impedido o desenvolvimento geral.

Vimos, na parte anterior, como a baixa produtividade da agricultura exerce influência desfavorável sôbre a espiral inflacionária dos preços de produtos agropecuários. Ademais, a baixa produtividade e a baixa renda per capita não permitem a formação de um mercado interno estável para os produtos manufaturados nacionais. Torna-se, portanto, de imperiosa necessidade coordenar a política de investimentos com a de expansão econômica, não sòmente entre os diferentes setores de atividades, em escala nacional, mas, sobretudo, entre as diversas regiões, onde predomine uma ou outra atividade econômica. $\mathbf{O}$ desenvolvimento de um setor (neste caso, a indústria) não favorece, necessàriamente, a expansão de outro (agricultura); ao contrário, o surto industrial de São Paulo drenou os recursos materiais e humanos (divisas fortes e mão-de-obra na melhor idade de trabalho) do Nordeste e de outras regióes do País. Não há, em absoluto, reciprocidade entre as regiões, como bem o comprova a inexistência de investimentos, até há pouco tempo, no Nordeste. A tendência atual de investir em empreendimentos industriais é consequiência direta da política do Govêrno que, através da suDENE de favores fiscais aos investidores e de outros meios ao seu alcance, procura diminuir o enorme atraso daquela região em relação ao Centro-Sul. O Gráfico 2 e o Anexo 3 permitem 
GRAFICO 2 :

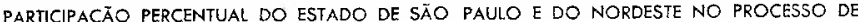
INDUSTRIALIZAÇÄO BRASIIEIRA $(1940$ A 1958)

OUTROS ESTADOS

S. PAULO -.-. NORDESTE

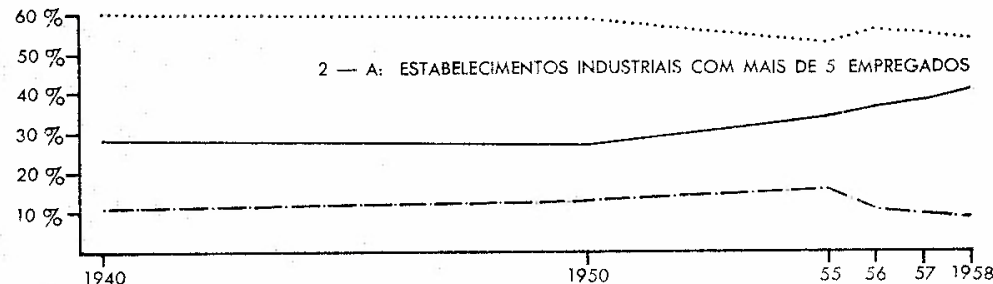

2 - B: PESSOAL EMPREGADO

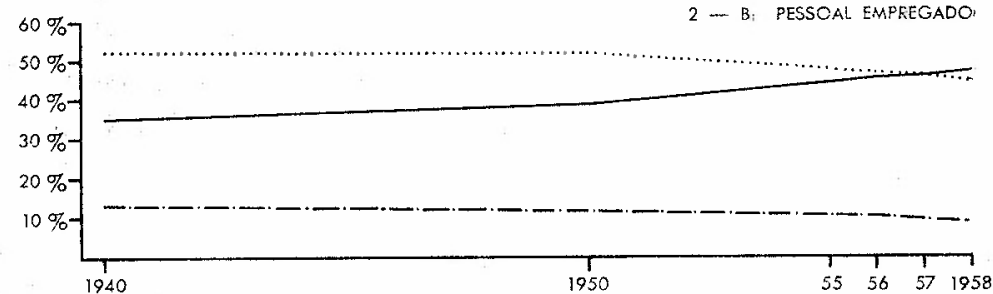

2 - C: SALÁRIOS PAGOS
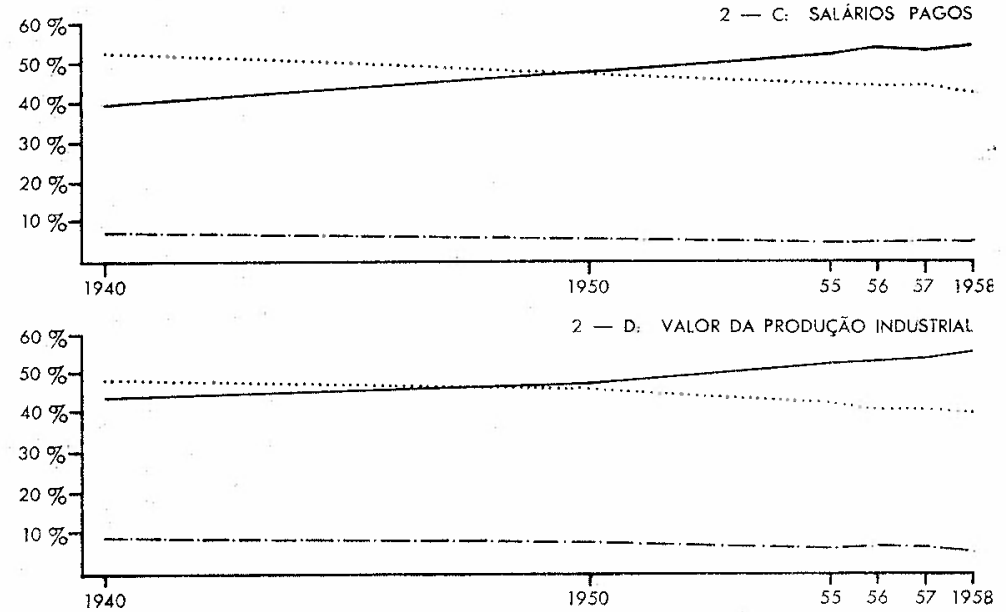
avaliar as tendências do processo de industrialização brasileira, principalmente no que se refere à participação do Estado de São Paulo e do Nordeste.

Os dados compilados para construção do Gráfico 2 (número de estabelecimentos industriais com mais de 5 emjregados, pessoal nêles empregado, salários pagos e valor ('a produção industrial) referem-se a seis anos diferentes, entre 1940 e 1958. Quando êsse trabalho foi feito ainda 4 ão haviam sido publicados os resultados do Censo de 1960. Entretanto, é inegável a tendência para a concentração da indústria, sob qualquer dos aspectos estudados, durante o mesmo período, no Estado de São Paulo, em comparação com uma diminuição correspondente, nos índices compilados, na parte do Nordeste e do resto do 3rasil. Assim, o número de estabelecimentos industriais com mais de 5 empregados, no Estado de São Paulo, cresceu $10,3 \%$ de $1940(28,8 \%$ ) a $1958(39,1 \%)$ sôbre o total brasileiro. No mesmo período a participação do NorLeste sofreu diminuição de $2.7 \%$.

I To que se refere ao pessoal empregado nesses estabelecimentos, as tendências discripantes são ainda mais nítidas: no período mencionado a participação de São Paulo aumentou, em têrmos relativos, $12,5 \%$, enquanto o Nordeste teve sua parcela reduzida em 5,3\%.

No caso de salários pagos podemos observar a mesma tendência: em 1940 a indústria paulista pagava 39,5\% do 'otal dos salários vigentes nos estabelecimentos industriais lo País com mais de 5 empregados; em 1958 a proporção cra de $53,5 \%$, com o acréscimo, portanto, de $14,0 \%$. No mesmo espaço de tempo, a parte do Nordeste foi reduzida de 7,2 para $4,2 \%$ sôbre o total brasileiro.

Tinalmente, no que tange ao valor da produção industrial, cuja importância se reflete diretamente nas arrecadações estaduais e federais e, indiretamente, nos niveis de renda e do bem-estar das populações, de 1940 até 1958, a parte correspondente ao Estado de São Paulo cresceu constantemente, a partir de $43,5 \%$, em 1940 , para ultrapassar $50,0 \%$ do valor da produção nacional, em 1955, e alcan- 
çar 55,0\% em 1958. Simultâneamente, a porcentagem do Ncrdeste decresceu de $8,2 \%$ para $5,2 \%$ do total nacional.

A mesma discrepância podemos verificar, ao examinar a distribuição de alguns fatôres básicos no processo da industrialização nas regiões ora estudadas. Conforme o Quadro 5, em 1960 cada habitante do Estado de São Paulo consumiu, aproximadamente, 17 vêzes mais energia elétrica e 6 vêzes mais cimento do que um nordestino; e dispôs ${ }^{\prime}$ de 5 vêzes mais rodovias asfaltadas e quase 7 vêzes mais veículos motorizados.

QUADRO 5: INDICES DE ALGUNS FATÔRES BASICOS NO PROCESSO DA INDUSTRIALIZAÇÃO (1960)

\begin{tabular}{|c|c|c|c|}
\hline Fatôres Básicos & Brasil & São Paulo & Nord -sie \\
\hline $\begin{array}{l}\text { Consumo de cimento (em to- } \\
\text { neladas) }\end{array}$ & 4.447 .318 & 1.527 .139 & $\mathbf{3 2 7 . 4 j 3}$ \\
\hline per capita & 0,063 & 0,118 & 0,021 \\
\hline $\begin{array}{l}\text { Consumc de energia elétrica } \\
(\epsilon: n \cdot 1.000 \mathrm{kw} / \mathrm{h})\end{array}$ & 18.345 .534 & 7.888 .958 & $559.4 \mathrm{C}$ \\
\hline per capita & 0,258 & 0,608 & $0,0:$ \\
\hline $\begin{array}{l}\text { Veículos a motor (passageircs } \\
\text { e carga) }\end{array}$ & 1.643 .673 & 381.767 & 69.19 \\
\hline (pcr 1.000 habs.) & 14,7 & 29,4 & 4,4 \\
\hline Veículos a motor (só carga) & 396.992 & 141.257 & 28.997 \\
\hline (por 1.000 habs.) & 5,6 & 10,9 & 1,8 \\
\hline $\begin{array}{c}\text { Extensão de rêde } \\
\text { em tráfego } \begin{array}{c}\text { rodoviária } \\
\text { (em }) *\end{array}\end{array}$ & 499.550 & 102.944 & $79.72 \mathrm{O}$ \\
\hline (por $1.000 \mathrm{~km}^{2}$ ) & 58,7 & 415,3 & 82,5 \\
\hline
\end{tabular}

* Dadcs referente's ao ano de 1961.

Fonte dos dadcs brutos: IBGE, Anuário Estatícticc tio Erasil, 1958 e 1962.

Vemos, portanto, confirmada a tese de que o impacto exercido pelo desenvolvimento industrial sôbre a vida econô- 
mica e social não atinge, necessáriamente, o País como um todo, mas apenas uma região restrita — na realidade, êle se restringe à área do "Greater São Paulo" — e não causa progresso econômico nas outras regiões; ao contrário, acentua as discrepâncias e diferenças estruturais existentes, em vez de diminuí-las.

Ao pauperismo relativo do Nordeste, acentuado pelo êxodo dos elementos potencialmente mais produtivos, vem-se juntar outro fenômeno prejudicial ao desenvolvimento, cu seja, a tendência migratória do capital privado. Em centros de expansão econômica a procura crescente de bens e serviços cria um impulso constante para a inversão e, à medida que esta aumenta, crescem também a renda global e per capita da região, o que tende a aumentar a demanda, provocando, assim, um movimento ascensional da economia como um todo. Ao contrário, em regióes onde os baixos níveis de renda per capita não permitem a poupança, os estoques de capital acumulados em épocas mais favoráveis vão diminuindo através da depreciação e da falta de reinvestimentos. Por outro lado, a grande pressão populacional obriga os podêres públicos a destinar maiores parcelas de seus parcos recursos aos setores de educação elementar, à saúde e a outras obras assistenciais, em detrimento de investimentos em obras públicas fundamentais ao desenvolvimento, tais como estradas, centrais energéticas etc. .

O Quadro 6 dá-nos idéia da tendência, observada no Brasil, no tocante às inversóes de capital nacional.

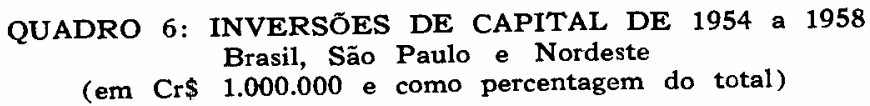

\begin{tabular}{|c|c|c|c|c|c|}
\hline Região Ano & 1954 & 1955 & 1956 & 1957 & 1958 \\
\hline Brasil & 15.128 .2 & 13.100 .5 & 16.208 .2 & 20.369 .0 & 33.478 .4 \\
\hline$\%$ & 100,0 & 100,0 & 100,0 & $1 C 0.0$ & 100,0 \\
\hline São Paulo & 5.354 .8 & 6.319 .9 & 8.700 .9 & 11.283 .4 & 21.004 .9 \\
\hline$\%$ & 35.4 & 48,2 & $\mathbf{5 3 , 7}$ & 55,4 & 62,2 \\
\hline Nordeste & 431.5 & 591.2 & 1.083 .0 & 1.046 .4 & 1.287 .7 \\
\hline$\%$ & 2,8 & 4,5 & 6,7 & 5.1 & 3,8 \\
\hline
\end{tabular}

Fonte dos dados brutos: IRGE, Anuário Eutatístico do Brasil, 1957, 1958 e 1951. 
Nas regiões pobres o diminuto poder de compra das populações condiciona uma demanda inicial de novos capitais em niveis baixos. Em outras palavras: não chega a criar um impulso expansionista. Nessas condiçóes a atuação de outros fatôres, que normalmente contribui para o crescimento econômico, impede a saída do impasse..$^{\top}$ Assim, o sistema bancário, se rão regulamentado para atuar diferentemente, tende a transformar-se $\mathrm{em}$ instrumento sugador dos lucros das regióes pobres, canalizando-os para as mais ricas e progressistas onde o rendimento do capital é mais
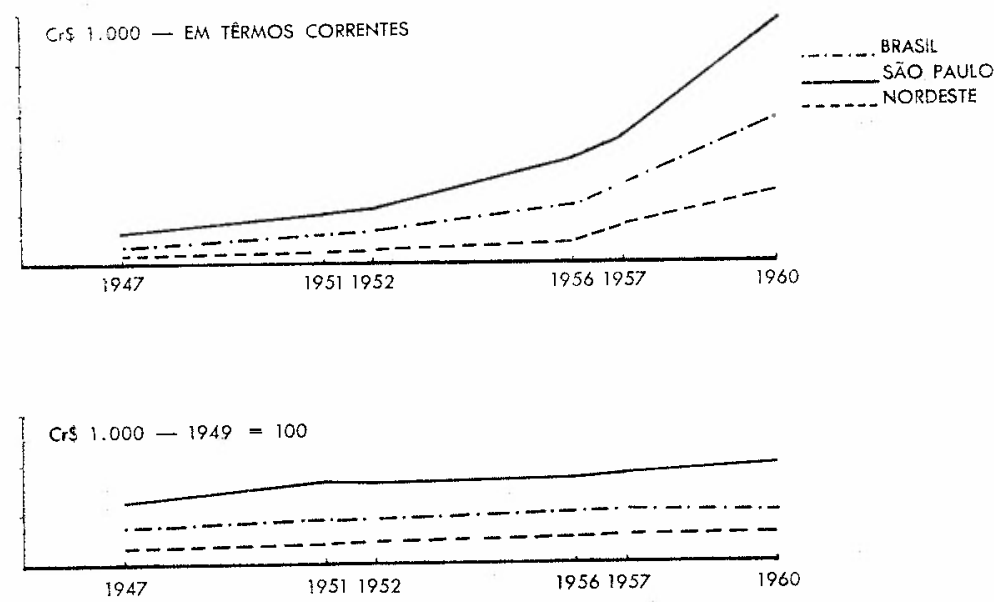

7) R. NURKse e G. MYRDAL, tratando do problema da formação de capital em paises subdesenvolvidos, prccuram determinar os fatồes necessários pera impulsionar o desenvolvimento. Entretanto, a análise de Nurkso, cperando com o conceito de "círcuio vicioso da pcbreza", náa consegue revelar a tendencia ao empreendimento progressivo, ressaltada por Myrdal quondo enuncia seli principio da "causação circular". Vide: R. Nurkse, Alguns Aspectos de la Acumulación de Capital en los Paises Subdesenvolvidos, Fondo de Cultura Económica, Mexico, 1952, págs. 13 e 14. G. MYrdal, Teoria Eccnomica y Regiones Subdesarrolladas, cap. II, Fondo de Cultura Eccnomica, México. 
elevado e mais seguro. O comércio opera sôbre as mesmas bases, isto é, em favor das regiões ricas e contra as pobres, e indústrias dos centros em expansão impedem a implantação e o desenvolvimento de congêneres em outras regiões.

Assim sendo, as regiões pobres continuam com a maior parte de suas populações ativas ocupada no setor primário, com equipamentos obsoletos, estrutura arcaica e renda per capita baixíssima; as rêdes de transporte, quando existem, também são antiquadas e ineficientes; os serviços públicos (energia, água, esgôto etc.) são inferiores, em quantidade e qualidade, aos das regiões mais adiantadas; a educação e a saúde encontram-se em estado precário. Finalmente, ao baixo nível educacional e cultural e ao primitivismo da mentalidade cívica daí resultante corresponde a violência de processos rudimentares.

A mão-de-obra barata e dócil, única "vantagem" das regiões pobres, não constitui em si um atrativo bastante forte para o nvestimento privado e para a instalação de emprêsas indultriais. A realidade mostra uma tendência inversa: a mão-de-obra procura os centros de expansão industrial.

A continuar aumentando as discrepâncias regionais em nível de renda e, conseqüentemente, em nível educacional, cultural e político, o abismo assim criado ameaça engolir as próprias estruturas sociais e políticas da Nação.

PRODUTO INTERNO, RENDA REAL E RENDA PER CAPITA

De tôdas as formas de desigualdade regional as que apresentam $o$ aspecto mais grave, em face das tendências e perspectivas do futuro, são a distribuição diferencial da renda territorial global entre as diversas regiões do País e a disparidade dos respectivos níveis de renda per capita. As discrepâncias na distribuiçấo da riqueza são sintomáticas da situação em que o dinamismo econômico se restringe a uma área privilegiada do território nacional - região Sul, em nosso caso, especialmente o Estado de São Paulo - em contraste com a estagnação, ou pior, com a tend $\hat{\text { nn- }}$ 
cia ao empobrecimento, absoluto e relativo, de grande parte da população brasileira.

- O Gráfico 3 e o Anexo 2 permitem uma comparação, não sòmente em têrmos nominais, mas também, relativos, da evolução da renda nacional, nas diferentes regiões do País, entre 1950 e 1960, bem como dos respectivos níveis de renda per capita, segundo os setores de atividade.

A primeira evidência que se nota ao se compararem os níveis de renda per capita é a persistência da desigualdade, com apenas insignificantes modificações, entre as diferentes regiões. Assim, a renda per capita no Estado de São Paulo continua apresentando um índice que corresponde a quase o dôbro do da renda nacional; o índice referente à renda per capita da região Leste, devido a influência do Estado da Guanabara, é quase idêntico ao índice per capita global, enquanto o resto do País (Nordeste, Norte e Centro-Oeste) continua com índices de 3 a 3,5 vêzes inferiores ao de São Paulo.

A comparação dêsses índices, todavia, não esclarece tôdas as tendências ao pauperismo progressivo das regiões rurais, devido à disparidade na etolução dos preços dos produtos agrícolas, em relação aos industriais. Sendo assim, a desprcporção será maior se atentarmos que, no Estado de São Paulo, 33, б\% da população ativa tira suas rendas de atividades primárias, com índice per capita de $\operatorname{Cr} \$ 87.100,00$ em 1960. No mesmo ano, no Nordeste, $68,0 \%$ da população ativa, ocupados no setor agropecuário, tiravam a ínfima renda per capita de $\operatorname{Cr} \$ 29.500,00$.

No que se refere ao setor de atividades industriais, $29,3 \%$ da população ativa do Estado de São Paulo, concentrados nesse setor, contribuíram com $33,2 \%$ da renda territorial global do Estado com o índice per capita de Cr\$ . . . . . 141.200,00; no Nordeste $9,8 \%$ da população ativa, contribuindo com $11,1 \%$ da renda territorial, apresentaram a rerda per capita de $\mathrm{Cr} \$ 47.300,00$. Caracterizando, assim, uma situação extrema de subdesenvolvimento, a região nordestina apresenta, mesmo nas atividades industriais, ní- 
GRÁFICO 4: INDICES DO PRODUTO REAL DE 1947 a 1960 $1940=100$

$$
\text { BRASLL ............ S. PAULO - - - NORDESTE }
$$

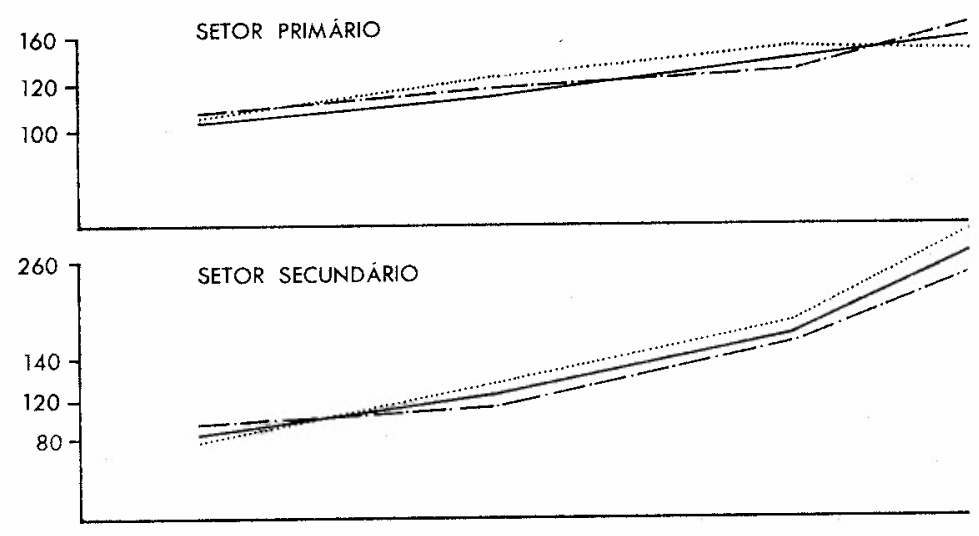

SETOR TERCIÁRIO
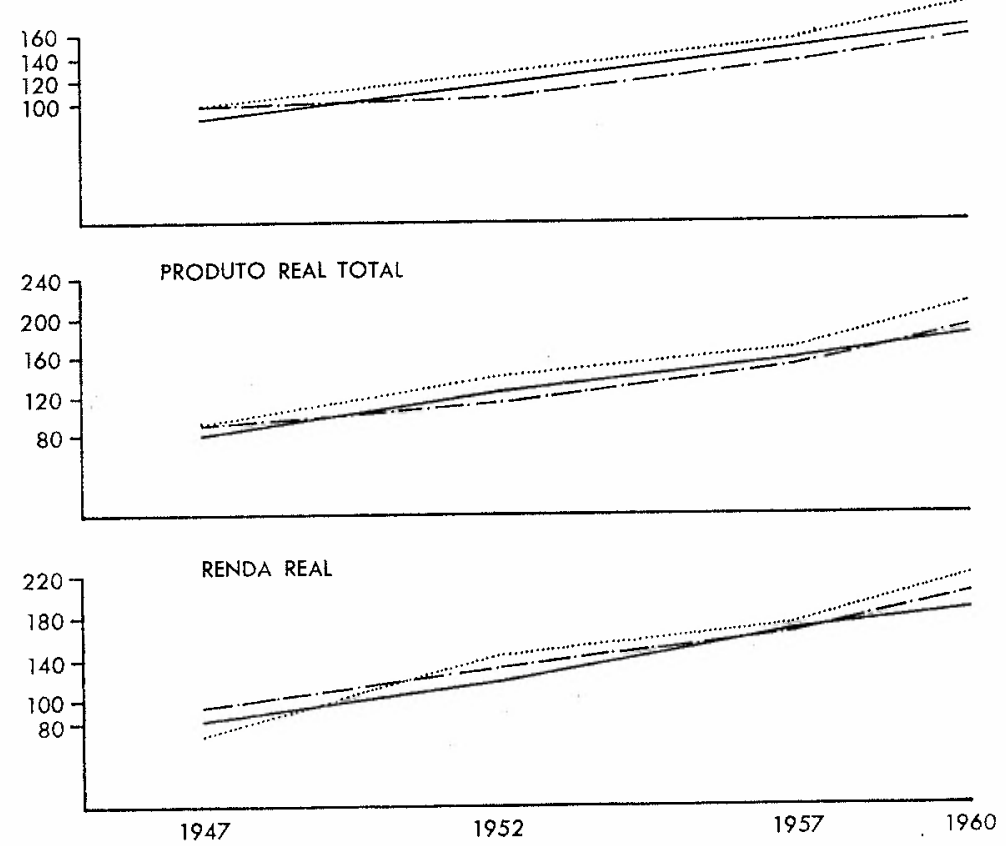
veis de renda muito inferiores aos da agricultura dos estados mais desenvolvidos da Federação.

INDICES E TAXAS DE CRESCIMENTO DO PRODUTO REAL

Devido à alta taxa de crescimento da população (3,1\% a.a. entre 1950 e 1960 e, segundo uma estimativa, 3,3\% a.a. entre 1960 e 1970), e devido, também, à já comentada proporção de inativos, torna-se necessário um alto nível de investimentos, ou seja, o crescimento do produto real, a fim de não só manter, mas, se possivel, melhorar o nível de vida da imensa maioria da população brasileira.

O problema fundamental está em saber se, apesar do progresso incontestável, a economia brasileira conseguirá manter, globalmente, o elevado ritmo de crescimento do quiinqüênio $1947 / 1952$, durante o qual a renda real cresceu $42,3 \%$. No quiinquiênio seguinte, $1952 / 1957$, as respectivas taxas diminuíram a ponto de deixar u'a margem menor entre o crescimento vegetativo da população e o da economia nacional. Mesmo proporcionando certo número de empregos novos cada ano, acolhendo os jovens que ingressam nas fileiras da população ativa, torna-se imprescindível, para sair do estágio de subdesenvolvimento, a absorção progressiva das massas rurais subempregadas, o que contribuirá para elevar a proporção da população ativa e, em consequiência, a renda per capita.

No Gráfico 4 e no Anexo 4 procuramos mostrar a evolução diferente, no que se refere ao crescimento quantitativo dos setores de atividade econômica, tanto em seus aspectos globais, quanto às mesmas discrepâncias regionais que acabamos de analisar.

Entre 1947 e 1960, o produto real brasileiro do setor primário cresceu apenas $72 \%$ contra o crescimento de $227,1 \%$ na indústria e de $87,6 \%$ no setor terciário. No mesmo período, as respectivas taxas para o Estado de São Paulo foram de 67,4, 252,4 e 100,0\%. O Nordeste apresenta, na mesma ordem: $64,1,164,0$ e $80,0 \%$. 
Os índices relativos ao crescimento do produto real total e da renda real durante o período acima, refletem, necessàriamente, as mesmas tendências: o aumento no Estado de São Paulo foi de 136,0 no produto real e de $150,4 \%$ na renda real contra apenas 102,8 e $121,4 \%$ no Nondeste.'

Uma renda de níveis baixos, que provenha, na maior parte, de atividades agropecuárias rudimentares, onde a produtividade é baixa, só pode assegurar aos produtores a subsistência; não é capaz de estimular poupanças e investimentos. A falta de uma política vigorosa de investimentos, combinada com um crescimento populacional acelerado, para o qual as migrações internas aos centros urbanos e industriais constituem solução muito precária e altamente prejudicial, pelos motivos expostos acima, não pode deixar de aumentar o desemprêgo disfarçado e, concomitantemente, fazer baixar os níveis de renda per capita em tcldos os setores da atividade humana.

\section{TAXAS DE CRESCIMENTO CONBINADAS}

Baseando-nos nos dados estatísticos compilados e discutidos acima, estamos agora em condições de verificar até que ponto a hipótese de Kuznets - segundo a qual o desenvolvimento econômico moderno se caracteriza por um aumento constante e acentuado da população, combinado com o crescimento acelerado da renda per capita - se aplica à realidade brasileira e, especialmente, às duas unidades da Federação, selecionadas para a comparação, 'o Estado de São Paulo e o Nordeste.

O Quadro 7 e os Anexos 5 e 6 fornecem-nos os índices que nos permitem analisar as tendências dos dados brasileiros. Todos os valôres apresentados neste trabalho referem-se apenas ao periodo de 1947 a 1960 , período êsse curto demais para permitir extrapolações a longo prazo. Todavia, parece-nos, os dados são suficientemente precisus

8) A diferença entre o produto réal e renda real deve-se às alteraçõ nas relações de troca. Vale dizer, a renda real é igual ao produto re: influenciado pelo comportamento dos preços de exportação com rcl-r̃̃ aos de importação. 
para podermos levantar hipóteses e analisar as perspectivas da economia brasileira a curto e médio prazos.

A pəpulação brasileira, entre 1947 e 1960, cresceu 46,5\%; 1 ouve, portanto, um aumento médio anual de $3,0 \%$. No mesmo tempo a renda real sofreu um incremento de $123,5 \%$, o que, em taxa média anual, representa $6,5 \%$. As respectivas taxas para o produto real foram de 112,0 e $6,0 \%$. No Estado de São Paulo a população aumentou, no mesno período, $52,7 \%$ (média anual de $3,5 \%$ ), a renda real subiu $150,4 \%$ (média anual de $7,3 \%$ ) e a renda per capita, apesar do aumento constante e vigoroso da populeçãz, cresceu 64,0\%, à razão, portanto, de 4,0\% por ano.

QUADRO 7: TAXAS PERCENTUAIS DE CRESCIMENTO DA POPULAÇÃO, DA RENDA E DO PRODUTO, DE 1947 A 1960

\begin{tabular}{|c|c|c|c|c|c|}
\hline Rezião & Discriminação & $1947 / 52$ & $1952 / 57$ & $1957 / 60 *$ & $1947 / 60$ \\
\hline \multirow{5}{*}{ E: 2 sil } & População & 13,7 & 15,6 & 11,2 & 46,5 \\
\hline & Renda Real & 42,3 & 33,3 & 20,4 & 128,5 \\
\hline & Renda Real & & & & \\
\hline & per capita & 25,2 & 15,1 & 8,3 & 56,2 \\
\hline & Prcdute Real & 34,8 & 29,2 & 21,7 & 112,0 \\
\hline \multirow{4}{*}{$\therefore$ ‥ Paulo } & População & 14,9 & 18,1 & 12,5 & 52,7 \\
\hline & $\begin{array}{ll}\text { Renda } & \text { Real } \\
\text { Renda } & \text { Real }\end{array}$ & 48,2 & 30,1 & 29,9 & 150,4 \\
\hline & per capita & 29,0 & 10,1 & 15,5 & 64,0 \\
\hline & Prcduto Real & 39,6 & 32,2 & 27,7 & 136,0 \\
\hline \multirow{4}{*}{ deste } & Populacãa & 11,7 & 11,1 & 8,2 & 34,4 \\
\hline & Renda Real & 35,0 & 34,4 & 22,0 & 121,4 \\
\hline & per capita & 20,7 & 20,8 & 12,5 & 64,1 \\
\hline & Prcduto Real & 26,5 & 29,8 & 23,4 & 102,8 \\
\hline
\end{tabular}

4. zices dos dados brutcs: 0 IBGE, Anuário Estatístico do Brasil, 1962;

- "O Brasil em Números", Apêndice do Anuário Estatistico do Brasil, IBGE, 1960;

- Revista Brasileira de Economia, FGV, n. ${ }^{\circ}$ 1, março/1959 E n.o 1, março/1962.

( . Os dados desta coluna referem-se a um período mais curto ou, mais i.....: iamente, aos 4 anos de 1957 a 1960.

Nics sote Estados do Nordeste, apesar de uma taxa de natalidade das mais altas do mundo, sua população aumentou, no mesmo espaço de tempo, apenas $34,4 \%$, com uma taxa média anual de $2,3 \%$. 
O produto real, no mesmo período, cresceu $102,8 \%$, com a taxa média de $5,6 \%$, e a renda real com, respectivamente, 121,4 e $6,3 \%$. Dessa forma, mesmo com uma taxa relativamente baixa de crescimento populacional, os baixos índices do produto real e da renda real no Nordeste näo permitiram elevar os níveis de renda per capita a ponto de criar um impulso inicial para a poupança e o desenvolvimento.

Isso significa, em têrmos reais, que longe de alcançar ou diminuir as diferenças em nível de vida com os Estados mais prósperos da União, o Nordeste, quando muito, manteve-se no mesmo nível, à mesma distância, sem conseguír beneficiar-se do notável desenvolvimento da última década. De fato, comparando os respectivos índices da renda real per capita, em 1947 e em 1960 a de São Paulo é exatamente igual a $377,0 \%$ da do Nordeste, em ambos os anos de referência.

CONSIDERAÇÕES FINAIS

Pretendeu-se, neste trabalho, analisar alguns aspectos e problemas do desenvolvimento econômico brasileiro, conferindo-se especial destaque às diferenças regionais. Pela comparação de índices econômicos e suas respectivas taxas de crescimento, tentamos apreender as tendências dos diversos processos, como a urbanização, a reestruturação da população ativa, a distribuição da renda nacional, etc. .

Todos os índices analisados mostram profundo desequilíbrio entre o "Estado-Líder" da União e os sete Estados do Nordeste. As taxas globais do Brasil são apenas médias ideais que ocultam a verdadeira situação. Sem dúvida, o Nordeste serviu apenas como parâmetro de comparação e, na realidade, conforme revelam os anexos, a posição das outras regiões do País, com exceção da Guanabara e algurs núcleos agrindustriais adjacentes às capitais estaduais, não é muito superior à do Nordeste. Dêsse modo, essas populações, longe de acompanharem a tendência quase universal, no mundo contemporâneo, para o desenvolvimento e para 
o conseqüente aumento de seu nível de vida, conseguem, na melhor das hipóteses, manter a distância que os separa dos "primos ricos", com todos os problemas políticos e sociais que essa situação gera para o processo de integração nacional.

Nos limites dêste trabalho não cabe uma análise minudente das medidas que se impõem aos podêres públicos no sentido de aliviar as tensões sociais e políticas criadas e mantidas acesas pelo desequilíbrio regional. Apontamos, a título de ilustração apenas, alguns fatôres capazes de modificar a panorama econômico-social do País, aproximando os extremos e estendendo os benefícios do desenvolvimento a tôdas as camadas sociais e a tôdas as regiões.

Além do contrôle da inflação, parece-nos de fundamental importância, para implantação de uma política de poupança e de inveśtimentos planejados, os seguintes problemas:

- o nível de investimentos ou de formação de capital, tanto no seu aspecto global quanto no regional; e

- a repartição equiitativa dos capitais investidos entre os diferentes setores da economia nacional.

É incontestável que, nos últimos quinze anos, tanto o setor particular quanto os podêres públicos deram ênfase e apoio especiais a tôdas as iniciativas do setor industrial, em detrimento direto da economia rural e indireto de tôda a população do País, que sofre as conseqüências de um processo inflacionário desenfreado.

Evidencia-se que a indústria atual depende, de maneira acentuada, de sua base agropastoril. Manifesta é essa dependência no tocante às necessidades de matérias-primas para a produção e de alimentos para a mão-de-obra. $\mathbf{O}$ campo, por outro lado, constitui mercado natural para os produtos manufaturados, que não raro encontram dificuldades de colocação nos mercados internacionais. "Uma elevação do produto real per capita nessas condições (de subdesenvolvimento) ficará limitada em seu alcance enquan- 
to rão se refletir numa elevação do produto per capita no setor primário."

O fomento e a assistência à agricultura tornam-se imperativos nas diretrizes de uma política econômica equilibrada. Como bem ressalton Bauer e Yaney, "pode-se afirmar, com certa segurança, que, pelo menos nos primeiros estágios do desenvolvimento, a assistência adequada à agricultura é a melhor garantia no sentido da criação e do desenvolvimento de um setor industrial viável."10

Essa assistência não deve expressar-se, necessàriamente, na manutenção de preços artificiais, em subsídios etc., mas, sim, no ensino de técnicas de irrigação, no fornecimento de : dubos, sementes selecionadas e, last but not least, na edučção e na politização das massas rurais.

Aliás, reputamos essenciais para a aceleração do desenvolvimento os investimentos no setor educacional e em pesquisas científicas e tecnológicas que visem à valorização do rer humano e estimulem sua participação ativa no processo de emancipação econômica do País. Com analfabetos ou $\mathrm{ccm}$ alfabetizados de instrução primária não se constrói uma nação moderna. O equipamento material e as estruturas sociais e políticas refletem, forçosamente, $o$ atraso co fator humano. $O$ custo social do desenvolvimento pode tornar-se demasiado caro para a Nação, se não forem tomaCas, em devido tempo, as medidas cabíveis. Porém, como :em ressalta Lewis: "o importante não são as metas projetadas, mas as medidas concretas que devam ser tomadas pa-a melhor aplicar os fatôres de produção: treinamento do operariado, melhoria da produtividade, alimentação, estímulo aos investimentos, etc.. Esta é a parte mais árdua a mais negligenciada do planejamento." ${ }^{\text {11 }}$

4) Simon KuzNETS, op. cit., pág. 59.

ic) P. BAUER e B. S. YANEY, The Economies of Underdeveloped Countries, James Nisbet and Co. Ltd., Cambridge University Prass, Londres, pég. 236.

11) A. W. Lewis, The Theory of Economio Growth, George Allen and Unwin Ltd., Londres, 1954, pág. 390 . 


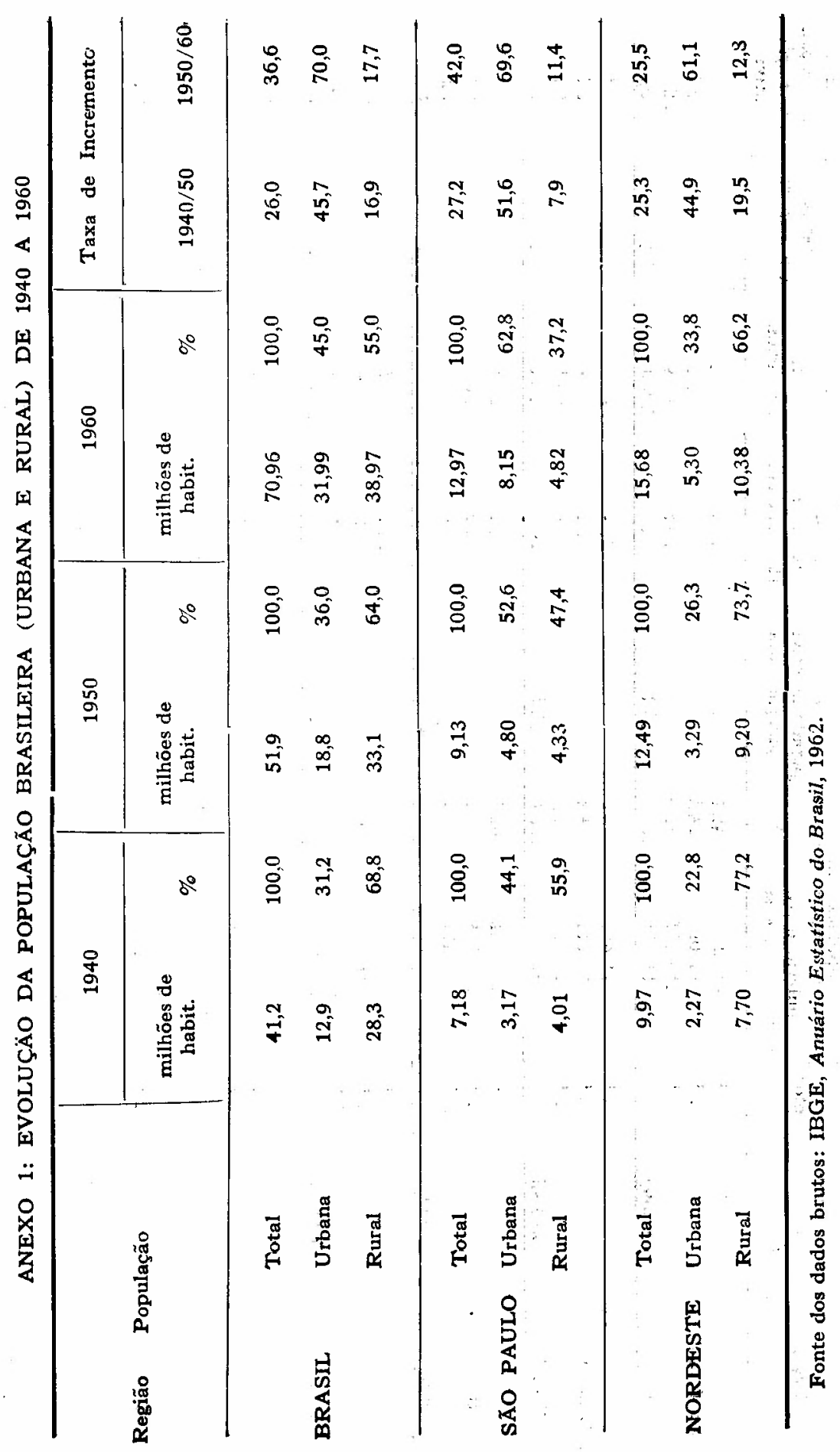




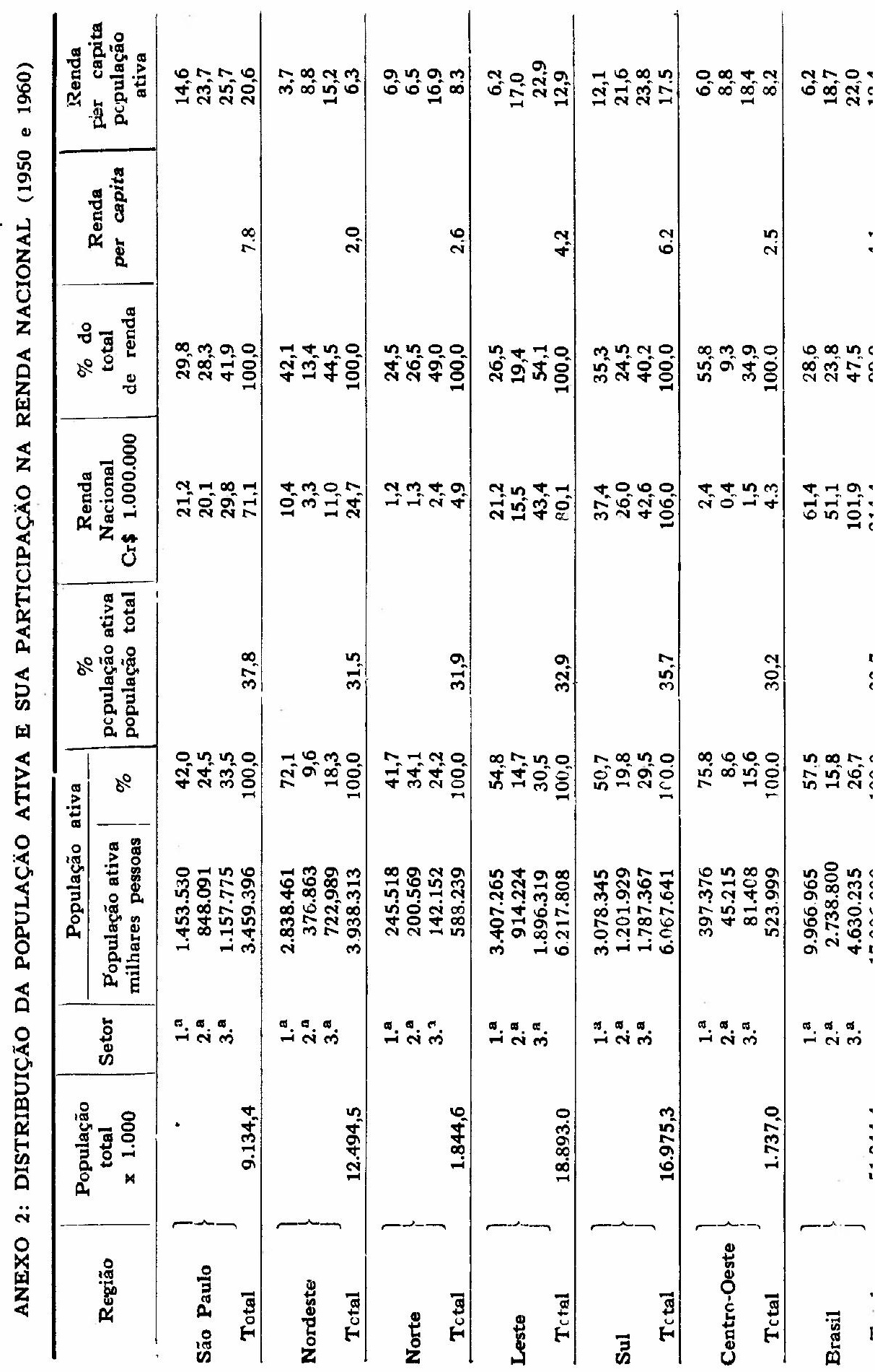




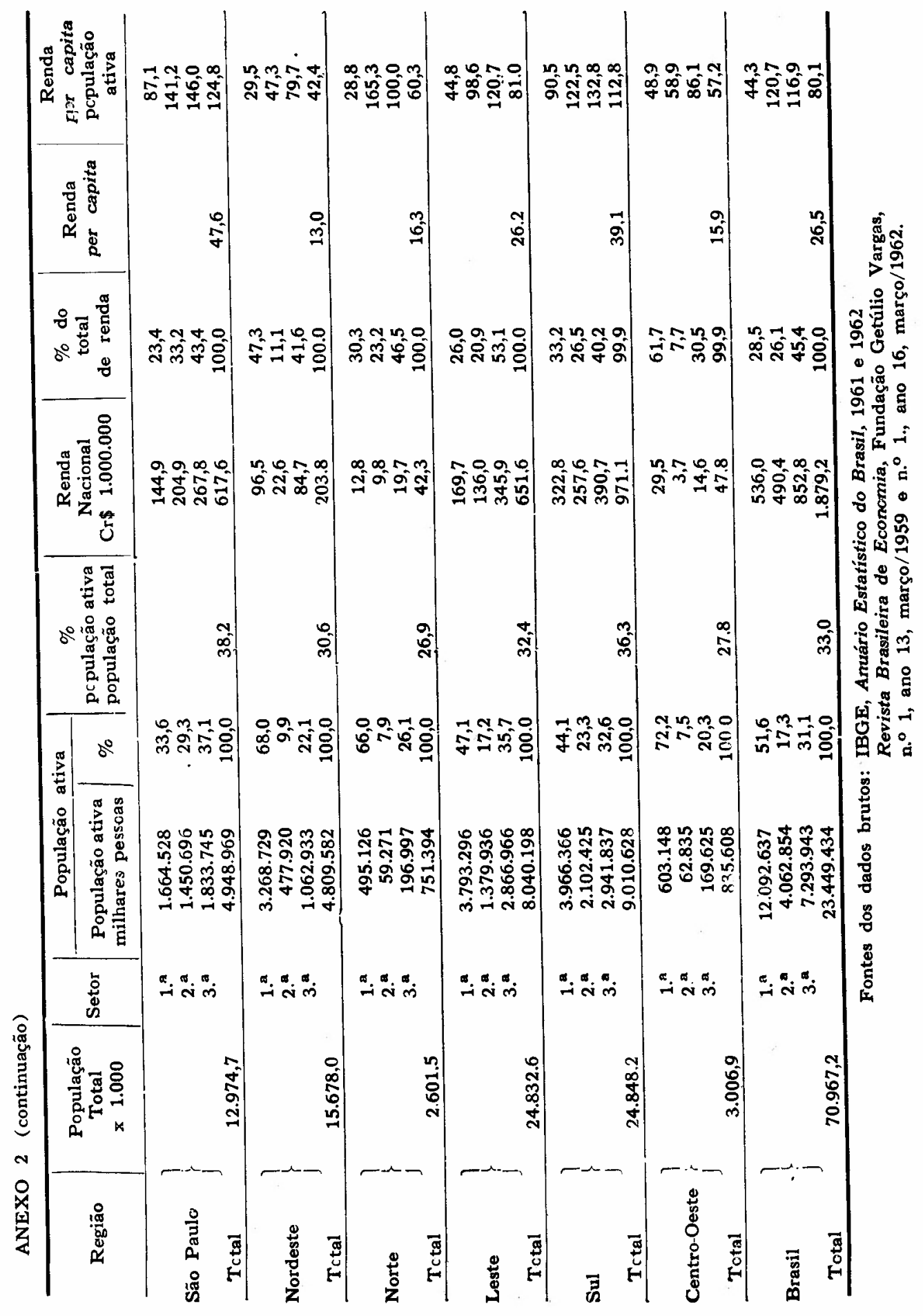




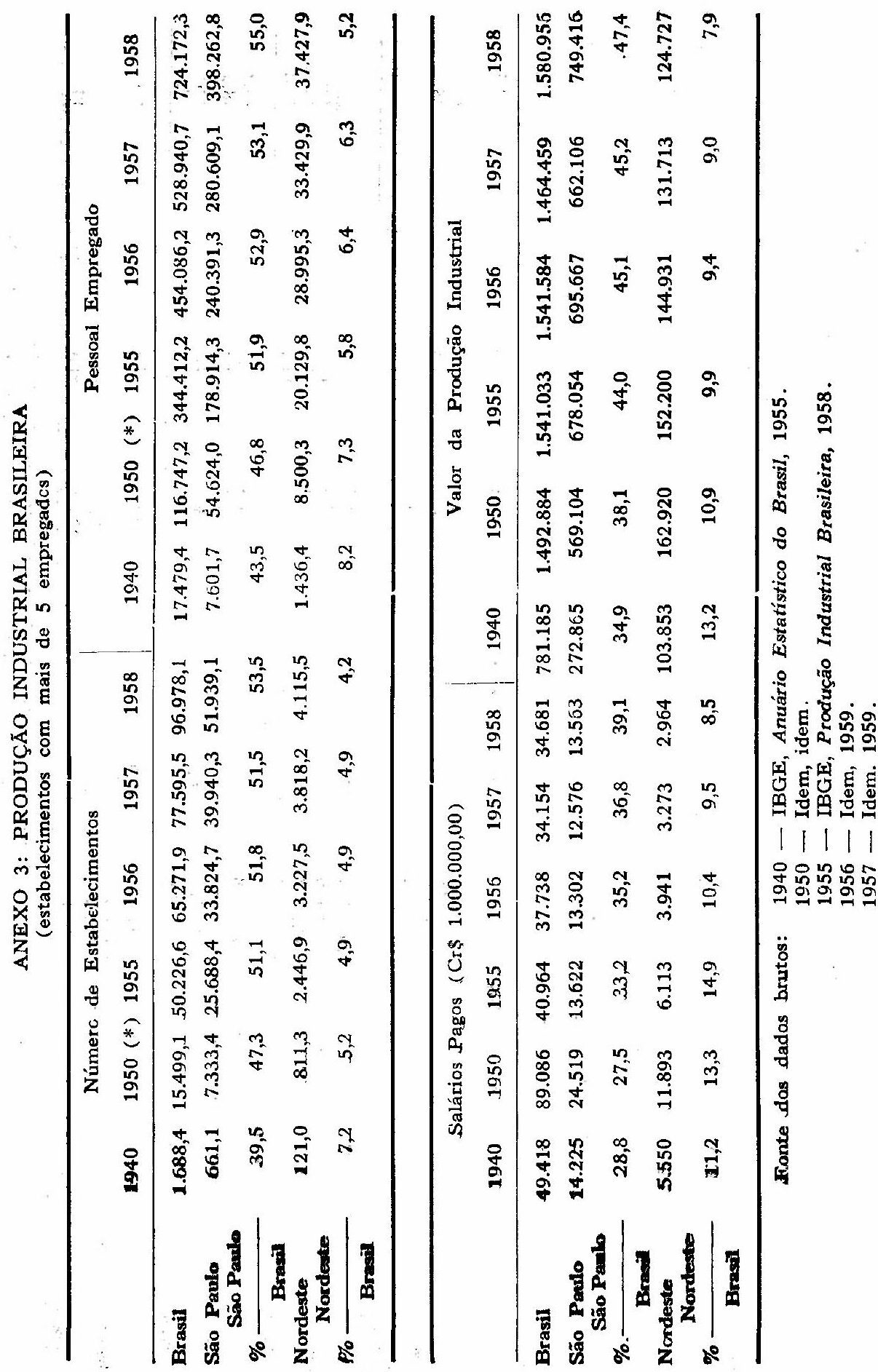




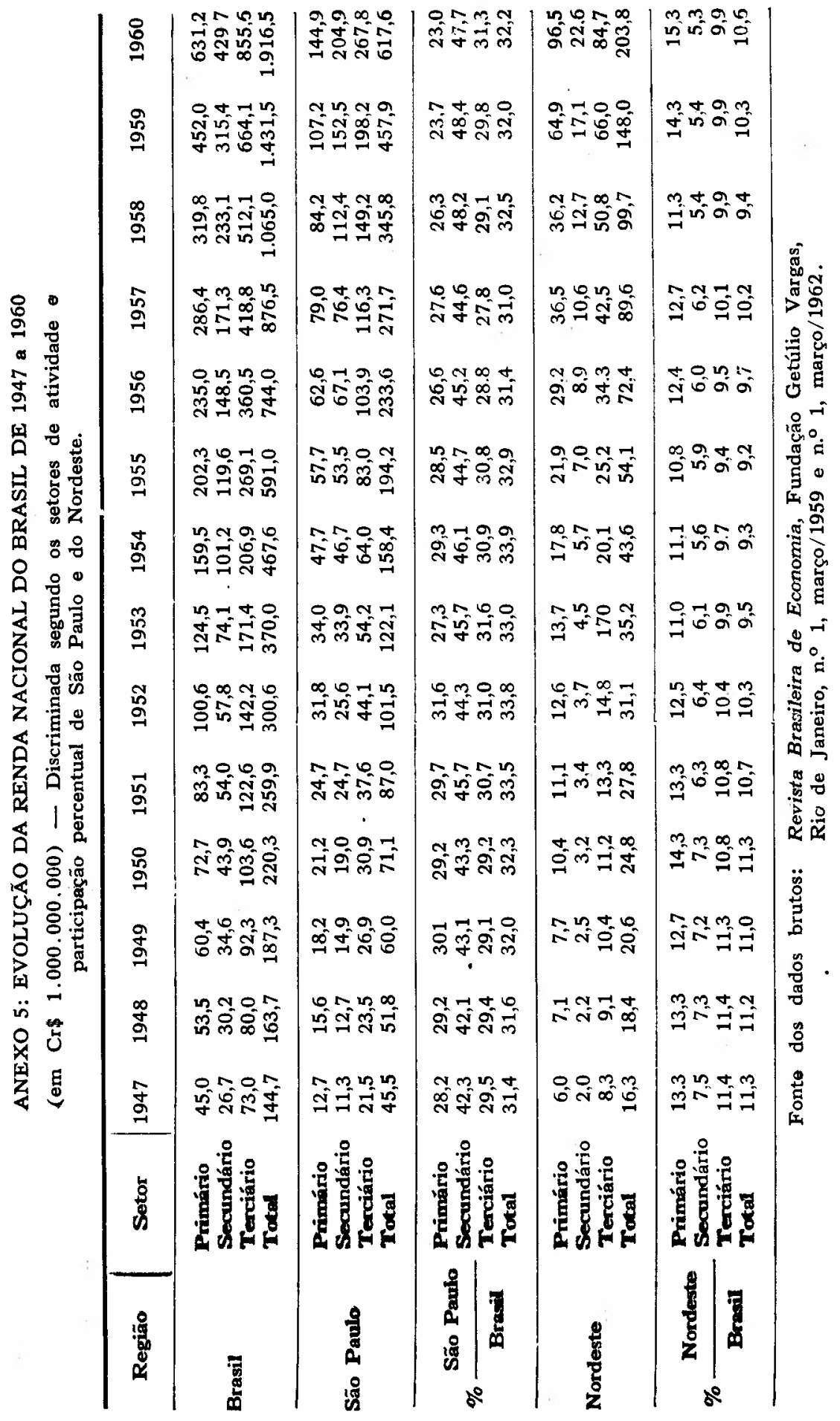




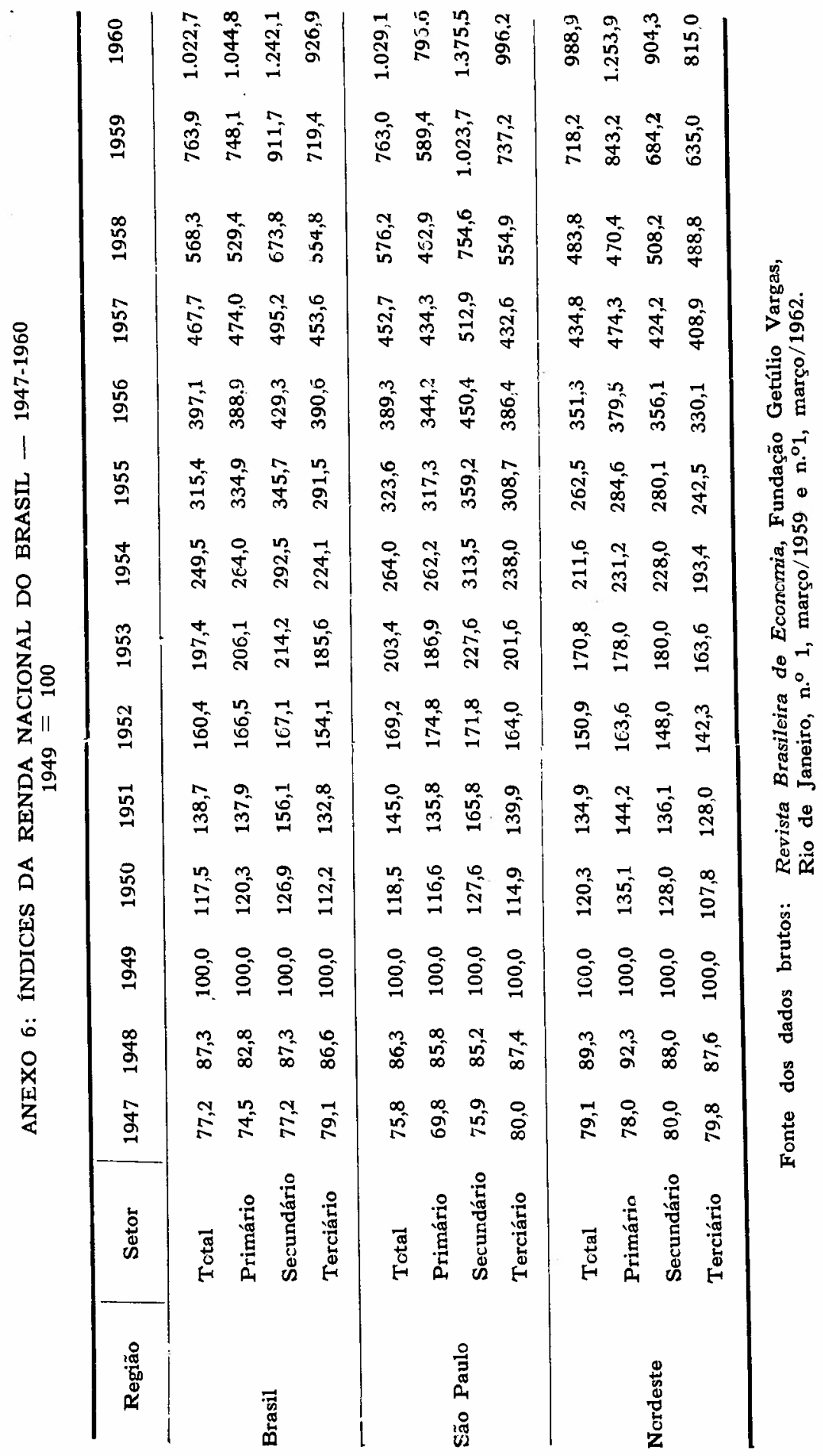

